\title{
Agronomic Characteristics and Nodules from Black Soybean Genotypes Due to Application Compost and Biochar as Sustainable Agriculture
}

\author{
Tien Turmuktini ${ }^{*}$, Dedi Mulyana ${ }^{1}$, R. Wahyono Widodo ${ }^{1}$, Elly Roosma Ria ${ }^{1}$, Endang \\ Kantikowati $^{2}$, Yenny Muliani ${ }^{3}$, Agung Karuniawan ${ }^{4}$ and Tualar Simarmata ${ }^{4}$
}

Date Received: $18^{\text {th }}$ December 2019 / Date Accepted: $27^{\text {th }}$ January 2020

\begin{abstract}
Purpose : Black soybean is a legume plant that has economic value on effective seeds and nodules, but out of the number of varieties that have been released until 2013 only 11 varieties are with agronomic height input innovation. The research objective is to obtain superior local genotype, as a source of new black soybean varieties, accompanied by compost and biochar-based agronomy practical innovations for sustainable agriculture.

Research Method: The first treatment was compost-based agronomy innovation with biochar $(B): b_{1}(1 t$ $\left.h a^{-1}+1 t h a^{-1}\right)$ and $b_{2}:\left(1.5 t h a^{-1}+0.5 t h a^{-1}\right)$. The second treatment was 4 genotypes of local black soybean $(G): K B 1, K A 3, C K 5, K H 4$, and as a comparison was a Cikuray variety with each treatment repeated three times. Anova test results of factorial patterns and DRMT Duncan's test at the $5 \%$ level.

Findings : Anova test results of factorial patterns and DRMT Duncan's test at the $5 \%$ level indicate that practical innovations based on compost and biochar agronomy accompanied by genotype have no effect. Both agronomy innovations $b_{1}$ and $b_{2}$ have the same effect on agronomic characters. Expected Genotypes that were superior to their agronomic character were shown by KH4 and KA3 genotypes with potential productivity of $3.28 \mathrm{th} \mathrm{a}^{-1}$ and $3.19 \mathrm{th} \mathrm{a}^{-1}$, and increased by $21 \%$ and $17.71 \%$, respectively. The genotypes of KB1, KA3 and KH4 produced the same number of nodules compared to Cikuray varieties.

Limitations : This research doesn't study about soil condition after the experiment.

Value : The novelty in this study is the use of low doses and directly applied to planting holes, obtained local genotypes superior agronomic characters for sources of new varieties, and obtained practical innovations based on compos and biochar agronomy for guidance for farmers who later selected regions as centers for varieties new black soybeans.
\end{abstract}

Keywords: compost, biochar, black soybean, agronomic characteristic, nodules

\section{INTRODUCTION}

Global warming has caused climate change, which encourages more frequent climate anomalies, such as El-Nino which causes drought or La-Nina which causes flooding. This situation is a challenge that needs to be sought a solution in the selection of new varieties of black soybeans, such as genotypes that are tolerant of climate change, drought, short-lived, disease-resistant, and widely adapted. Other advantages can be categorized at high yield levels over varieties that have been released (Menteri Pertanian RI. 2014 and
Balai Penelitian Tanaman Aneka Kacang dan Umbi. 2016), commercial values of the seeds such as antioxidant content, namely, dissolved phenolics (isoflavones and anthocyanins) (Kye

\footnotetext{
I* Faculty of Agriculture, Winaya Mukti University, Sumedang, West Java, Indonesia.

t.turmuktini@yahoo.com

2 Faculty of Agriculture, Bale Bandung University, Bandung, West Java, Indonesia.

3 Faculty of Agriculture, Islam Nusantara University, Bandung, West Java, Indonesia.

${ }^{4}$ Faculty of Agriculture, Padjadjaran University, Bandung, West Java, Indonesia.

DD ORCID http://orcid.org/0000-0002-1201-5504
} 
Man Cho, et al., 2013), levels of protein and carbohydrates, as a raw material for soy sauce and ingredients potential active for human health such as phenols, tannins and isoflavones (Debby, et al., 2017), and oil content as a source of renewable fuels (Adi, et al ., 2014, Chindy, et al., 2015, Ruvin, et al., 2019).

$\mathrm{KB} 1, \mathrm{KA} 3, \mathrm{KH} 4$ and $\mathrm{CK} 5$ genotypes are local Indonesian soybean genotypes, a collection of plant breeding laboratories at the University of Padjadjaran, which is being continuously investigated. In 2013 the results of multilocation tests in 10 regions in Indonesia, including lowlands, medium and high, these four genotypes were revealed adaptive genotypes in the highlands, (Jatinangor area at an altitude of $780 \mathrm{~m}$ above sea level) and the results were higher than average results in 10 of these multi-location test areas (Chindy, et al., 2015). Genotypes response is influenced by GEI (genotypes x Environment Interaction) or GGE (Genotype and genotype by environment Interaction). The significance value of GEI and GGE to the results shows that some genotypes are more stable in other environments (Ayda and Muchlish Adie, 2018; Yan., et al. 2000). Thus, the response of genotypes is used as a basis for the practical management of agronomy to choose suitable soybean development areas (Law and. James, 2011).

In the practical management of agronomy, low input agriculture innovations are needed, efficient, economical and applicable. Adding organic compos and biochar material to low organic soil is an effort to ameliorate the soil so that the application of plant nutrients can be more effective (Lehmann, 2007). In general, the provision of organic material will improve the physical, chemical, biological biology and yield of plants (Briljan, et al., 2017; Gerard, et al., 2018; Barrow, 2012; Lehmann, et al., 2011) according to the characteristics of the genotype agronomics. Various forms of organic matter can be provided, depending on the availability at the farmer's level including sheep manure and rice husk for easy application. Application compost $25 \%$ and biochar $75 \%$ of (recommended dosage of compost $2 \mathrm{t} \mathrm{ha}^{-1}$ and biochar $30 \mathrm{t} \mathrm{ha}^{-1}$ ) can increase the number of nodules per plant, the number of effective nodules, and soybean yield (Ruvini, et al., 2019). Provision of biochar $5 \mathrm{t}$ $\mathrm{ha}^{-1}$ is not enough to increase the $\mathrm{pH}$ of Ultisol soils in the humid tropics. Biochar needs to be applied approximately every third season, similar to conventional liming, and the dose needs to be increased to $15 \mathrm{t} \mathrm{ha}^{-1}$. The use of biochar is highly recommended for agricultural land in acid soils (Gerard, et al., 2018).

The high dosage of the two ingredients was apparently not applicable and economical for farmers because of the height input of agriculture. From the calculation of the biochar rusk inventory, it turns out that 1 ha of paddy fields (yield of $5 \mathrm{t} \mathrm{ha}^{-1}$ ) produces about 6 tons of organic material (straw) and 2 tons of husk per harvest, from the $50 \%$ organic material to compost $3 \mathrm{t} \mathrm{ha}^{-1}$ and 1 ton ha ${ }^{-1}$ to biochar rusk. Therefore, the novelty in this study is the use of low doses and directly applied to planting holes, obtained local genotypes superior agronomic characters for sources of new varieties, and obtained practical innovations based on compos and biochar agronomy for guidance for farmers who later selected regions as centers for varieties new black soybeans.

\section{MATERIALS AND METHODS}

The study was conducted in the experimental garden of the Faculty of Agriculture, University of Winaya Mukti, Indonesia, from May to August 2016 at an altitude of $850 \mathrm{~m}$ above sea level. The experiment was carried out by factorial randomized block design which was repeated three times. The first factor is the practical innovation of compost and biochar (B) based agronomies, namely: $\mathrm{b}_{1}\left(1 \mathrm{t} \mathrm{ha}^{-1}+1 \mathrm{t}\right.$ $\left.\mathrm{ha}^{-1}\right)$ and $\mathrm{b}_{2}\left(1.5 \mathrm{t} \mathrm{ha}^{-1}+0.5 \mathrm{tha}^{-1}\right)$. The second factor is the local genotype of black soybean (G), 4 genotypes, namely KA3, KB1, CK5, KH 4 and Cikuray varieties as a comparison. The ingredients consist of manure sheep's compost, biochar rice husk (which is burned in pyrolysis with temperatures around $300-400^{\circ} \mathrm{C}$, urea fertilizer $(45 \% \mathrm{~N}) 50 \mathrm{~kg} \mathrm{ha}^{-1}, \mathrm{KCl}\left(60 \% \mathrm{~K}_{2} \mathrm{O}\right)$ $50 \mathrm{~kg} \mathrm{ha}^{-1}$ and SP36 $\left(36 \% \mathrm{P}_{2} \mathrm{O}_{5}\right) 75 \mathrm{~kg} \mathrm{ha}^{-1}$. 


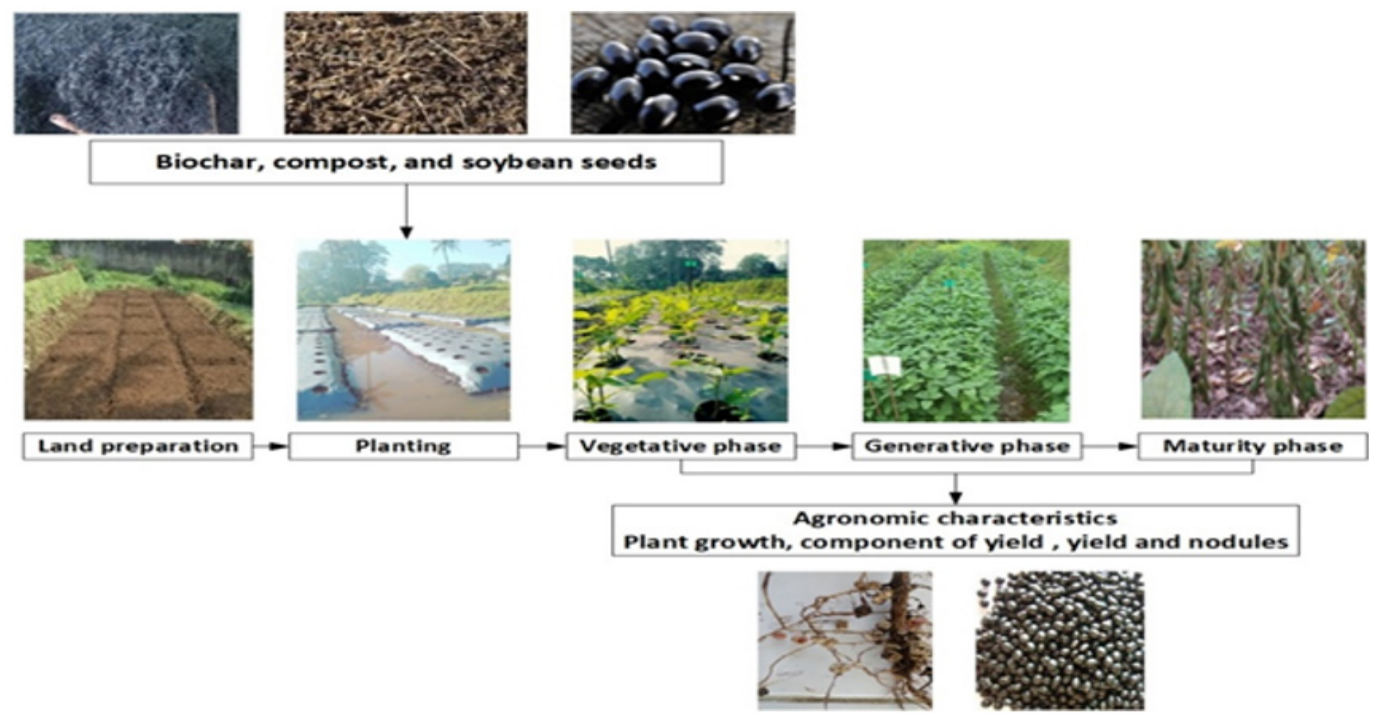

\section{Figure 01: Flowchart of research}

Data were analyzed using ANOVA and DRMT/ Duncan's tests at the level of 5\%. The experiment was carried out on moor fields with $125 \mathrm{~cm}$ x $200 \mathrm{~cm}$ plot size of 30 plots (one plot consisted of 25 plants). plants per treatment plot with a spacing of $25 \mathrm{~cm} \mathrm{x} 40 \mathrm{~cm}$. Compost and biochar applications are carried out when planting by mixing the two ingredients then put into the planting hole, then filled with 2 seeds. Application of N, P, K fertilizer is given from the age of 14 DAP/ Days. After Planting, Fertilizer $\mathrm{N}$ is given twice (each half dose at the age of 14 DAP and 35 DAP), Fertilizer P and $\mathrm{K}$ are given all doses at age 15 DAP. The measured parameters are the characteristics of growth, nodules, component yield and yields. The flowchart of research is shown in Figure 01.

\section{RESULTS AND DISCUSSION}

\section{Result}

\section{Growth Phase}

Supporting observations results (data not analyzed) of soil conditions before the study consisted of andisols, medium C-organic level (2.16\%), medium N-total (0.30\%), medium $\mathrm{C} / \mathrm{N}$ ratio (12), medium $\mathrm{P}_{2} \mathrm{O}_{5}$ (35.00 mg $100 \mathrm{~g}^{-1}$ ), high P available Bray 1 (14.00 $\left.\mathrm{mg} \mathrm{kg}^{-1}\right)$, low $\mathrm{K}_{2} \mathrm{O}\left(18.00 \mathrm{mg} 100 \mathrm{~g}^{-1)}\right.$. The soil cation composition Na-dd $\left(0.00054 \mathrm{cmol} \mathrm{g}^{-1}\right)$ is very low, Ca-dd ( $\left.7.16 \mathrm{cmol} \mathrm{g}^{-1}\right)$ is medium, $\mathrm{Mg}$-dd $(2.12 \mathrm{cmol}$ $\left.\mathrm{g}^{-1}\right)$ is high and $\mathrm{K}-\mathrm{dd}\left(0.35 \mathrm{cmol} \mathrm{g}^{-1}\right)$ is low, CEC (37 $\left.\mathrm{cmol} \mathrm{g}^{-1}\right)$ is classified as high, low of $\mathrm{pH}(4.4 \mathrm{in} \mathrm{KCl}$, 6.0 in water). Climatic conditions such as daily air temperature around $22-32^{\circ} \mathrm{C}$, rain fall around 4.5-135.5 $\mathrm{mm}$ per month, humidity during the study around 60$80 \%$ per month and climate classification is rather wet $(51.38 \%)$. Based on the environmental conditions, it turns out that the four genotypes of adaptive soybean plants live in this environment. Figure 02 indicates the results of observations of plant growth phases, for 4 local genotypes that have different phase ages compared to Cikuray varieties as a comparison.

\section{Agronomics characteristic}

\section{Growth and nodules}

The ANOVA and the DRMT Duncan's test level 5\% statistical analysis results at the level of $5 \%$ indicate that the agronomy practical innovations based on compost and biochar (B) are: $\mathrm{b}_{1}\left(1 \mathrm{tha}^{-1}+1 \mathrm{tha}^{-1}\right)$ and $\mathrm{b}_{2}\left(1.5 \mathrm{tha}^{-1}+0.5 \mathrm{t}\right.$ ha $\left.^{-1}\right)$, with 4 genotypes (G) of KB1, CK3, KH4, and CK 5 as well as Cikuray as a comparison showed no influence on all measured agronomic parameters. The independent test results showed that agronomic practical innovations (B) had no significant effect, but the use of genotypes (G) showed an influence on agronomic traits, except shoot roots aged 14 DAP and 28 DAP and the weight of nodules per plant as shown in the Table 01. 


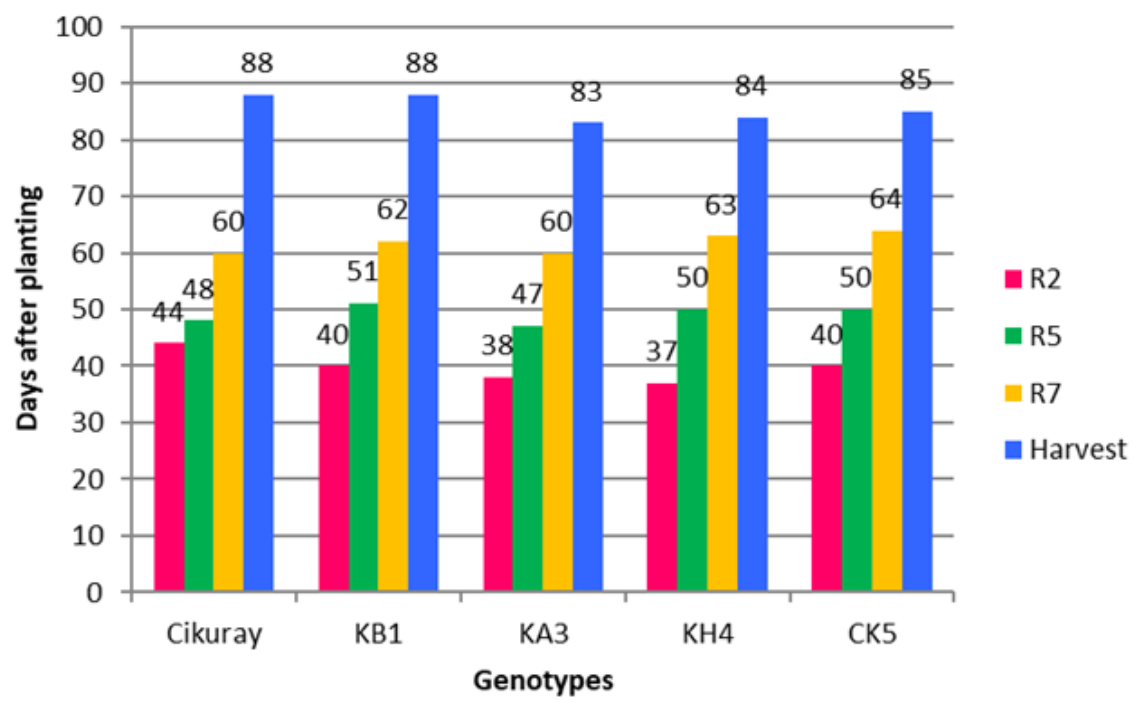

Figure 02: Phase R2 (Flowering), R5 (Pod filling), R7 (Mature) and Harvest of Black Soybean Genotypes

Table 01: Growth, nodules, components of yield and the productivity of back soybeans genotypes at different combinations of compos and biochar

\begin{tabular}{|c|c|c|c|c|c|c|c|c|}
\hline \multirow{3}{*}{$\begin{array}{c}\text { Treatments } \\
\text { B }\end{array}$} & \multicolumn{6}{|c|}{ Growth } & \multicolumn{2}{|c|}{ Nodules } \\
\hline & \multicolumn{3}{|c|}{ Plant height $(\mathrm{cm})$} & \multicolumn{3}{|c|}{ Shoot Root Ratio } & \multirow{2}{*}{$\begin{array}{l}\begin{array}{c}\text { Number } \\
\text { Plant }^{-1}\end{array} \\
42 \text { DAP }\end{array}$} & \multirow{2}{*}{$\begin{array}{c}\begin{array}{c}\text { Weights } \\
\text { Plant }^{-1}\end{array} \\
42 \text { DAP }\end{array}$} \\
\hline & 14 DAP & 21 DAP & 35 DAP & 14 DAP & 28 DAP & 42 DAP & & \\
\hline $\mathrm{b}_{1}$ & $11.964 \mathrm{a}$ & $21.17 \mathrm{a}$ & $46.20 \mathrm{a}$ & $2.44 \mathrm{a}$ & $2.10 \mathrm{a}$ & $3.90 \mathrm{a}$ & $25.67 \mathrm{a}$ & $0.41 \mathrm{a}$ \\
\hline $\mathrm{b}_{2}$ & $12.228 \mathrm{a}$ & $21.96 \mathrm{a}$ & $46.43 \mathrm{a}$ & $2.21 \mathrm{a}$ & $2.42 \mathrm{a}$ & $4.03 \mathrm{a}$ & $28.27 \mathrm{a}$ & $0.52 \mathrm{a}$ \\
\hline \multicolumn{9}{|l|}{ Genotip(G) } \\
\hline Cikuray & $15.43 \mathrm{~d}$ & $27.82 \mathrm{~d}$ & $53.94 \mathrm{c}$ & $2.53 \mathrm{a}$ & $2.28 \mathrm{a}$ & $5.40 \mathrm{~d}$ & $32.17 \mathrm{~b}$ & $0.41 \mathrm{a}$ \\
\hline KB 1 & $12.45 \mathrm{c}$ & $23.23 \mathrm{c}$ & $46.11 \mathrm{~b}$ & $2.60 \mathrm{a}$ & $1.98 \mathrm{a}$ & $4.38 \mathrm{c}$ & $24.50 \mathrm{ab}$ & $0.52 \mathrm{a}$ \\
\hline KA 3 & $14.87 \mathrm{~d}$ & $26.31 \mathrm{~d}$ & $53.10 \mathrm{c}$ & $2.32 \mathrm{a}$ & $2.19 \mathrm{a}$ & $4.08 \mathrm{bc}$ & $33.00 \mathrm{~b}$ & $0.41 \mathrm{a}$ \\
\hline KH 4 & $9.92 \mathrm{~b}$ & $16.86 \mathrm{~b}$ & $43.037 \mathrm{~b}$ & $1.88 \mathrm{a}$ & $2.28 \mathrm{a}$ & $2.56 \mathrm{a}$ & $32.17 \mathrm{~b}$ & $0.52 \mathrm{a}$ \\
\hline CK 5 & $7.91 \mathrm{a}$ & $13.62 \mathrm{a}$ & $35.38 \mathrm{a}$ & $2.29 \mathrm{a}$ & $2.55 \mathrm{a}$ & $3.42 \mathrm{~b}$ & $13.00 \mathrm{a}$ & $0.41 \mathrm{a}$ \\
\hline \multicolumn{9}{|c|}{ components of yield and the yields } \\
\hline (B) & $\begin{array}{l}\text { Number of } \\
\text { pods plant }^{-1}\end{array}$ & $\begin{array}{c}\text { Number } \\
\text { of seeds } \\
\text { plant }^{-1}\end{array}$ & $\begin{array}{c}\text { Weight } \\
\text { of seeds } \\
\text { plant }^{-1}\end{array}$ & $\begin{array}{l}100 \mathrm{sec} \\
\text { wei }\end{array}$ & $\begin{array}{l}\text { ds dry } \\
\text { ght }\end{array}$ & $\begin{array}{l}\text { Weight of } \\
\text { Seeds plot }^{-1}\end{array}$ & $\begin{array}{l}\text { Yield } \\
\mathrm{t} \mathrm{ha}^{-1}\end{array}$ & $\begin{array}{c}\text { Increase }^{-} \\
(\%)\end{array}$ \\
\hline b1 & $37.21 \mathrm{a}$ & $72.73 \mathrm{a}$ & $10.04 \mathrm{a}$ & & $16.27 \mathrm{a}$ & $706.67 \mathrm{a}$ & 2.82 & 0 \\
\hline b 2 & $36.41 \mathrm{a}$ & $70.51 \mathrm{a}$ & $10.07 \mathrm{a}$ & & $16.30 \mathrm{a}$ & $709.67 \mathrm{a}$ & 2.83 & 0.36 \\
\hline \multicolumn{9}{|l|}{ Genotip $(G)$} \\
\hline Cikuray & $33.33 \mathrm{~b}$ & $65.05 \mathrm{~b}$ & $8.95 \mathrm{a}$ & & $15.69 \mathrm{ab}$ & $677.50 \mathrm{abc}$ & 2.71 & 0 \\
\hline KB 1 & $34.53 \mathrm{~b}$ & $65.87 \mathrm{~b}$ & $9.68 \mathrm{a}$ & & $15.96 \mathrm{~b}$ & $663.33 \mathrm{ab}$ & 2.65 & -2.21 \\
\hline KA 3 & $24.82 \mathrm{a}$ & $45.50 \mathrm{a}$ & $8.01 \mathrm{a}$ & & $18.73 \mathrm{c}$ & $798.33 \mathrm{bc}$ & 3.19 & 17.71 \\
\hline KH 4 & $24.82 \mathrm{a}$ & $64.15 \mathrm{~b}$ & $9.50 \mathrm{a}$ & & $17.83 \mathrm{bc}$ & $820.83 \mathrm{c}$ & 3.28 & 21.00 \\
\hline CK 5 & $54.83 \mathrm{c}$ & $117.53 \mathrm{c}$ & $14.15 \mathrm{~b}$ & & $13.20 \mathrm{a}$ & $580.83 \mathrm{a}$ & 2.32 & -14.39 \\
\hline
\end{tabular}

DAP/ Days After Planting. Followed by the same letter within each column were not significantly, different at the 5\% level by DRMT Duncan,s test. 


\section{Yield components and the Yields}

The ANOVA and the DRMT Duncan's test level 5\% statistical analysis results at the level of $5 \%$ indicate that the agronomy practical innovations based on compost and biochar (B) are: $\mathrm{b}_{1}\left(1 \mathrm{t} \mathrm{ha}^{-1}+1 \mathrm{tha}^{-1}\right)$ and $\mathrm{b}_{2}\left(1.5 \mathrm{tha}^{-1}+0.5 \mathrm{t}\right.$ ha $^{-1}$ ), with 4 genotypes (G) of KB1, CK3, KH4, and CK 5 as well as Cikuray as a comparison showed no influence on all measured agronomic parameters. The independent test results showed that agronomic practical innovations (B) had no significant effect, but the use of genotypes $(\mathrm{G})$ showed an influence on components of yield and the yields as shown in the Table 01 .

In the Table 01: the CK5 could increase the productivity component such as the number of pods, number of seeds, and weight of seeds per plants. Along with the increase of 100 dry weight seeds quality, the weight of seeds per plot also increases the productivity $\left(\mathrm{t} \mathrm{ha}^{-1}\right)$. The highest productivity was obtained by $\mathrm{KH} 4$ and $\mathrm{CK} 3$, potential productivity of $3.28 \mathrm{tha}^{-1}$ and $3.19 \mathrm{tha}$ ${ }^{1}$, respectively, and increase of $21 \%$ and $17.71 \%$ respectively. Thus, the genotype superior agronomic characteristics were KH4 and CK3, because they yielded a high productivity with a great seed of quality. This genotype is expected to be a source of new superior varieties at 850 $\mathrm{m}$ above sea level. With the same number of nodules as the Cikuray variety, it means that innovative agronomic practices based on compos and biochar can create an environment that is equally representative.

\section{DISCUSSION}

The growth in the Table 01: The plant height and shoot ratio of various genotypes at various ages show the diversity. Generally, the Cikuray variety shows the higher results compared to the 4 genotypes, and this is because the Cikuray variety has a broad adaptability and has been released by the government (Balai Penelitian Tanaman Aneka Kacang dan Umbi. 2016). There is no interaction of the measured agronomic character, possibly because composer and biochar (B) based agronomic practice innovations were firstly given into the research area, so their effects on plants have not been significantly apparent in one planting season. Briljan, et al., (2017), stated that to see an increase in soil properties and productivities requires a long time, biochar has the effect of neutralizing the $\mathrm{pH}$ which was initially slightly acidic to neutral, but to get a neutral $\mathrm{pH}$ on acidic soil requires repetition every third season with a dose of $15 \mathrm{t} \mathrm{ha}^{-1}$. An application of $\mathrm{B}$ enhances C-organic so that there is an internal interaction between both of them in supporting a representative environment. Likewise, the response to the 4th genotype $(\mathrm{G})$ on the two agronomic practices (B) innovation is more influenced by innate genes. Innate genes will dominate the phenotypic expression. Another possibility is that the given amount of biochar is too small, but the addition of biochar will reduce the crop productivity (Gerard, et al., 2018)

The Nodules in the Table 01: It appears that the black soybean genotype produces the nodules that are the same number as the Cikuray variety (as a comparison variety), while the weight of nodules has no significant effect. This depends on the cooperation, presence and activity of rhizoid microorganisms that can tether $\mathrm{N}_{2}$ in the air with its host plants. This is supported by (Lehmann, 2007; Sohi, et al. 2010) as stated that biochar has variable effects on soil microbes associated with plants and root nodulation by Rhizobia (generally increasing, due to efficient nitrogen fixation). Also, Iijim, et al (2015) states that biochar might be an artificial shelter for soybean nodule bacteria. The use of organic fertilizers can increase the number of nodules per plant: and the number of effective nodules due to combining compost $25 \%$ and biochar $75 \%$ of the compost dose $\left(2 \mathrm{t} \mathrm{ha}^{-1}\right)$ and biochar $30 \mathrm{t} \mathrm{ha}^{-1}$ (Ruvini., et al. 2019). However, in this study the 4 genotypes were more dominant in expressing the same as Cikuray, and it was possible because environmental factors were in accordance with their needs (Couso and Fernandez. 2012).

In the Table 01: the CK5 could increase the productivity component such as number of pods, number of seeds, and weight of seeds per plants. Along with the increase of 100 dry weight seeds quality, the weight of seeds per 
plot also increases the productivity $\left(\mathrm{t} \mathrm{ha}^{-1}\right)$. The highest yields was obtained by KH4 and CK3, potential productivity of $3.28 \mathrm{tha}^{-1}$ and $3.19 \mathrm{tha}^{-}$ ${ }^{1}$, respectively, and increase of $21 \%$ and $17.71 \%$ respectively. Thus, the genotype superior agronomic characteristics were KH4 and CK3, because they yielded a high productivity with a great seed of quality. This genotype is expected to be a source of new superior varieties at 850 $\mathrm{m}$ above sea level. With the same number of nodules as the Cikuray variety, it means that innovative agronomic practices based on compos and biochar can create an environment that is equally representative.

Khais, et al (2016), stated that the appearance of 16 genotypes of black soybean intercropped with maize, showed diversity in each genotype. This shows the stress of the influential environment. The ability of a genotype to environmental fluctuations is determined by its plasticity and phenotypic changes are triggered by variations in the dimensions of space and time.

\section{CONCLUSIONS}

Practical innovations based on compost and biochar based on genotype have no influence. The two agronomic innovations $b_{1}\left(1 \mathrm{tha}^{-1}+1\right.$ $\left.\mathrm{t} \mathrm{ha}^{-1}\right)$ and $\mathrm{b}_{2}\left(1.5 \mathrm{t} \mathrm{ha}^{-1}+0.5 \mathrm{t} \mathrm{ha}^{-1}\right)$, have the same effect on agronomic characters. Genotype expectation with superior agronomic character was shown by KH4 and KA3 genotypes with potential yield of $3.28 \mathrm{t} \mathrm{ha}^{-1}$ and $3.19 \mathrm{t} \mathrm{ha}^{-}$ 1 , respectively, and increased by $21 \%$ and $17.70 \%$. The genotypes of KB1, KA3 and KH4 produced the same number of nodules compared to Cikuray varieties.

\section{Data Availability Statement}

The datasets generated during and/or analysed during the current study are available from the corresponding author on reasonable request.

\section{ACKNOWLEDGMENTS}

The authors would like to thank BP3IPTEKs West Java a contributor to the research Fund, and rector of the Faculty of Agriculture at Winaya Mukti University that has given this research supports.

\section{REFERENCES}

Adi, M. M., and A. Krisnawati. (2014). Soybean Opportunity as Source of New Energy in Indonesia. Int. J. Renew. Energy Dev. 3(1):37-43. https://www.researchgate.net/publication/275571230. DOI: https://doi.org/10.14710/ijred.3.1.37-43

Ayda Krisnawati and M. Muchlish Adie. (2018). GGE Biplot Analysis of Multi-Environment Yied Trials in Soybean Promoting Lines. Agricultural Science. 3 (2): 72-81.https://journal.ugm. ac.id/jip/article/view/33593. DOI: https://doi.org/10.22146/ipas.33593

Balai Penelitian Tanaman Aneka Kacang dan Umbi/Balitkabi. (2016). Deskripsi Varietas Unggul Kedelai 1918-2016. P 1 - 87. http://balitkabi.litbang.pertanian.go.id/wp-content/ uploads/2016/09/kedelai.pdf. DOI: https://doi.org/10.14692/jfi.12.2.39

Barrow, C. J. (2012). Biochar: Potential for Countering Land Degradation and for Improving agriculture. Applied Geography. 34(2012):21-28. https://www. Science direct.com/science/ article/abs/pii/S0143622811001780. DOI: https://doi.org/10.1016/j.apgeog.2011.09.008 
Sohi. S. P, E. Krull, E. Lopez-Capel and R. Bol. (2010). Chapter 2- A Review of Biochar and Its Use and Function in Soil. Advances in Agronomy. 105(36): 47-82, Burlington: Academic Press. https://www.sciencedirect.com/science/ article/ pii/S0065211310050029. DOI: https://doi. org/10.1016/s0065-2113(10)05002-9

Briljan Sudjana, Anggi Jingga and Tualar Simarmata. (2017). Enriched Rice Husk Biochar Ameliorant to Increase Crop Productivity on Typic Hapludults. Global Advanced Research Journal of Agricultural Science. 6(5): 108-113. ISSN: 2315-5094. https://www.researchgate. net/profile/Tualar_Simarmata/publication/318129065

Couso, L. L. and R. J. Fernandez. (2012). Phenotypic Plasticity as an Index of Drought Tolerance in Three Patagonia Steppe Grasses. Ann. Bot. 110 (4):849-857. https://academic.oup.com/ aob/article/110/4/849/149468. DOI: https://doi.org/10.1093/aob/mcs147

Chindy Ulima Zanetta 2014. Stability and Adaptability, Component of Yield and Yields of Black Soybeans Potential Genotypes in Java Island/Stabilitas dan Adaptasi Hasil Genotip Potensial Kedelai Hitam di Pulau Jawa.Thesis. Padjadjaran University . https://www.researchgate.net/ profile/Chindy_Zanetta/publication/271138214

Chindy Ulima Zanetta, Budi Waluyo, Meddy Rachmadi, and Agung Karuniawan. (2015). Oil Content and Potential Region for Cultivation Black Soybean in Java as Biofuel Alternative. Energy Procedia. 65 (2015): 29 - 35. https://pdf.sciencedirectassets.com/277910/1. DOI: https://doi.org/10.1016/j.egypro.2015.01.025

Debby Moody Sumanti, Imas Siti Setiasih, Roostita L.Balia, Agung Karuniawan, Hendronoto Arnoldus and W. Lengkey, (2017). Bioactive Compounds and Functional Properties of Some Flour Composites in the Manufacturing of Functional Food Products. Scientific Papers Series Management, Economic Engineering in Agriculture and Rural Development. 17 (3): 411- 417. http://managementjournal. usamv.ro/ pdf/ vol.17_3/Art59.pdf

Gerard Cornelissen, Jubaedah, Neneng, L. Nurida, Sarah E. Hale. Vegard Martinsen, Ludovica Silvania, and Jan Mulder. (2018). Fading Positive Effect of Biochar on Crop Yield and Soil Acidity During Five Growth Seasons in an Indonesian Ultisol. Science of the Total Environment. 634 (2018): 561-568. https://www.sciencedirect.com/ science/article/pii/ S0048969718311409. DOI: https://doi.org/10.1016/j.scitotenv.2018.03.380

Iijima1, Koji Yamane, Yasuhiro Izumi, Hiroyuki Daimon and Takayuki Motonaga1. (2015). Continuous Application of Biochar Inoculated with Root Nodule Bacteria to Subsoil Enhances Yield of Soybean by the Nodulation Control Using Crack Fertilization Technique Plant Prod. Sci. 18(2): 197-208. file:///C:/Users/ASUS/Documents/Pustaka\% 20 kedelai \%20hitam/nodule\%20soybean\%20iijima.pdf. DOI: https://doi.org/10.1626/pps.18.197

Khais Prayoga, M, Meddy Rachmadi, and Noladhi Wicaksano. 2016.Yield Characters of 15 Black Soybean Genotypes (Glycine soja. L.) Merr) in Inter Cropping Pattern of 2:1 with Corn, Jurnal Agrikultura. 27 (2): 89-93. ISSN 0853-2885 Jurnal. unpad.ac.id/ agrikultura/article/ view/9988/4466. DOI: https://doi.org/10.24198/agrikultura.v27i2.9988

Kye Man Cho, Tae Joung Ha, Yong Bok Lee, Woo Duck Seo, Jun Young Kim, Hyung Won Ryu, Seong Hun Jeong, Young Min Kang, and Jin Hwan Lee. (2013). Soluble Phenolics and Antioxidant Properties of Soybean (Glycine max L.) Cultivars with varying Seed Coat Colors. Journal of Functional Foods. 5(3): 1065-1076 . https://www.sciencedirect.com/ science/article/abs/pii/S1756464613000716. DOI: https://doi.org/10.1016/j.jff.2013.03.002 
Law, R. J, and A.T. James. (2011). Application of Physiological Understanding in Soybean Improvement. I Understanding Phonological Constraints to Adaptation and Yield Potential. Crop Pasture Sci. 62 (1): 1-11. http://www.publish.csiro.au/cp/CP10289 DOI: https://doi. org/10.1071/cp10289

Lehmann, J. (2007). Bio-Energy in The Black. Front in Ecol and the Environ. 5(7): 381-387. https://esajournals.onlinelibrary.wiley.com/doi/full/10.1890/1540.

Lehmann Johannes, Matthias C.Rillig, Caroline A . Masiello, William C.Hockaday and David Crowley. (2011). Biochar Effects on Biota - A Review. Soil Biology and Biochemistry.; 43:1812-1836. https://www.sciencedirect.com/science/article/abs/pii/ S003807171100 1805. DOI: https://doi.org/10.1016/j.soilbio.2011.04.022

Menteri Pertanian RI. 2014. Surat keputusan No. 1174/Kpts/SR.120/11/2014 dan No. 1175/Kpts/ SR.120/11/2014 tentang Pelepasan Varietas Unggul Mutiara 2 dan Mutiara 3 http://tip. trunojoyo.ac.id/semnas/

Ruvini Senevirathne, Somasundaram Sutharsan, Shanmugalingam Srikrishnah and Alagakone Paskaran. 2019. Research Article Evaluation of Applying Different Levels of Compost and Biochar on Growth Performance of Glycine $\max$ (L.). Open access. Asian J. Biol. Sci. 12(3):482-486. ISSN 1996-3351. https://www.researchgate.net/profile/Shanmugalingam_ Srikrishnah/publication/332763117. DOI: https://doi.org/10.3923/ajbs.2019.482.486

Weikai Yan, L.A. Hunt, Qinglai Sheng and Zorka Szlavnics. 2000. Cultivar Evaluation and MegaEnvironment Investigation Based on the GGE Biplot. Crop Sci. 40 (3):597-605. https:// dl.sciencesocieties.org/publications/cs/abstracts/40/3/597. DOI: https://doi.org/10.2135/ cropsci2000.403597x

Yan W, Hunt LA, Sheng Q, Szlavnics Z 2000. Cultivar evaluation and mega-environment investigation based on the GGE biplot. Crop Sci., 40 (3):597-605. DOI: https://doi. org/10.2135/cropsci2000.403597x 